\title{
Growth and Pattern of Women's Studies in Malaysia as Reflected by Generated Literature
}

\author{
A.N. Zainab \\ Library \& Information Science Unit,, Faculty of Computer Science and \\ Information Technology, University of Malaya, Kuala Lumpur, \\ 50603 Kuala Lumpur, Malaysia \\ e-mail: zainab@um.edu.my
}

\begin{abstract}
The study uses research-based resources listed in two published bibliographies on "Women in development in Malaysia" produced between the pre 1970 years and 2004 to describe the growth and pattern of women's studies in Malaysia. A total 4037 resources formed the basis of the study. Bibliometric measure are used to indicate the annual growth of literature over the periods, the preferred publication channels used by the authors, the subject areas of research interests, the active authors and the inference of collaboration based on co-authored works. The results indicate a growth in women's studies especially between 1990 and 2004 totaling 3346 publications, averaging about 258 titles per year compared to the average of 36 titles for the pre 1970 and 1989 years. There were heavier activities in economic studies, social-cultural studies, women's health and welfare and women in literature. The main types of publication produced are undergraduate academic research reports, master dissertations and doctoral theses. Conference presentations and journal articles are equally popular. Most authors in this field are one time contributors and only 18 authors produced 10 or more publications each. The majority of authors work alone indicating a low collaboration rate. The study proposes a collaborative e-bibliographic initiative to serve and sustain researchers' information needs in this field.
\end{abstract}

\section{Introduction}

Data from the Department of Statistics Malaysia (2005) indicated that out of the estimated population of over 26 million, males outnumbered females by about 104 males to every 100 females. However, enrolments in schools and universities indicated higher percentages of females (74\%) compared to males (67\%). The female life expectancy is also higher than for males especially for those within the 60-64 age groups. The statistical data also indicated that the proportion of single women aged between 20 and 34 increased from $43.2 \%$ in 1991 to $49.1 \%$ in 2000 and a higher proportion of young adults tended to marry at a later age. The statistics therefore indicate that the female population forms nearly half of Malaysia's population, a higher percentage of them are enrolled in secondary and higher educational institutions, and a higher percentage of those between 20 to 34 are unmarried and tend to marry late. This picture makes women's studies essential in order to ensure that women contribute productively to Malaysia's economic growth as they form a large proportion of the nation's potentially available labour force.

The business of libraries in this situation is in making sure that serious literature on women in Malaysia is controlled bibliographically and systematically acquired. The health of research activities in a discipline is often reflected by the amount of literature it 
generates. For collection development librarians, identifying what has been published can be quite a tricky business especially when the types of literature generated are those not easily obtained from the usual commercial channels of publishers and bookshops. As a result, acquisitions librarians often resort to using compiled bibliographies and listings of resources when ascertaining what is available, so that an educated decision can be made about what to purchase or acquire. Compiling bibliographies or creating listings of documents to support research activities or to enable acquisition and collection development is a traditional role of libraries. Bibliography itself is an ancient genre and is considered a scholarly practice (Bates, 1976; Hendry \& Carlyle, 2006). Hendry and Carlyle (2006) further explained that this scholarly practice encompasses, scoping and collating the items to a specific domain related to faculty research activities, using clear rules about what to include or exclude, organizing the items into logical categories, using a standard unit of what should be included in describing the items and packaging it in the form of a published monograph, weblogs or web bibliographies.

This article will indicate how the growth and pattern of women's studies in Malaysia can be gauged from resources listed in two published bibliographies on women in development in Malaysia, the first covered literature before 1970 to 1990 (Jamilah, 1991) and the second covered studies between 1990 and 2004 (Zainab, 2006). The study scoped itself to these two bibliographies for two reasons. Firstly, no dedicated web bibliography on women can be found originating from Malaysia except for one compiled by the Berkeley library (Darby Williams, 1999-2006), which listed only 98 titles. Secondly, the two bibliographies provide historical bibliographic data by virtue of the period covered, pre 1970s to 2004, and as such, trends and research productivity could be observed. The observed trends of generated literature would be useful for librarians in developing collections to sustain research activities in this area of study.

The earliest bibliography compiled on women in Malaysia was published in 1981 by the National Library of Malaysia (Bibliografi .., 1981). This first bibliography was 31 pages and was updated in 2002 (Bibliografi wanita .., 2002, 129p.). In the same year Fan (1981) compiled a "Bibliography on women in Malaysia" and this was published as a chapter in a book by Hing, Nik and Rokiah (1984). Fan (1982) later extended her bibliography to include women studies in Southeast Asia. This was followed by a 77-page bibliography published in 1984 by the National Development and Family Planning Board, Malaysia, a government agency (Wanita.., 1984) and this might be the bibliographical manuscript which Jamilah (1991, v) had mentioned locating at the National Family Planning and Development Board library. The Malaysian government's interest in collating information on the role of Malaysian women in development was manifested through the setting up of a National Clearinghouse on Women in Development under the Prime Ministers Department and aimed at enhancing awareness on the role and needs of women. The Clearinghouse prepared a 167 page bibliography in 1987 (Women's bibliography, 1987) to provide a resource base in support of national programmes. Fan's 1981 bibliography was reproduced in Jamilah's 1991 publication and Jamilah herself extended the coverage of literature produced on women up to 1989. There have been attempts to produce special listings such as on "Women and the media" (Bibliografi wanita.., 1991 and "Theses on women in Malaysia” (Dayang, 1995). An annotated bibliography was also published by the Sabah State Library (Dayang, 1996) and Khoo (1991a; 1991b) wrote an informative 
bibliographic essay in which she traced the efforts undertaken to bibliographically control literature on women in Malaysia. A sequel to Jamilah's bibliography was published in 2006 (Zainab, 2006) covering literature on women's studies in Malaysia produced between the period 1990 and 2004.

\section{Methodology}

This article used the resources listed in both Jamilah's (1991) and Zainab's (2006) bibliographies to ascertain the publication activities on women in Malaysia. Entries from the other bibliographies were counter checked to ascertain complete coverage. However, the earlier bibliographies compiled by the National Library Malaysia (Bibliografi .., 1981; Bibliografi wanita .., 2002) and the Population and Family Development Board Malaysia (Wanita.., 1984) have included high proportion of "popular" resources. The bibliographies by Jamilah and Zainab cover research-based literature from the pre 1970 years to 2004 and have excluded popular articles published in magazines and the newspapers. Research-based literature refers to works generated from undergraduate, graduate and doctoral research activities, papers presented at conferences, journal articles, and chapters in books, research reports, monographic series and books. Jamilah's bibliography had listed titles under two separate chapters, where chapter 2 was the reproduction of Fan's 1981 bibliography entitled, "Women studies in Malaysia: a bibliography covering the period prior to 1980" and chapter 3 was her own contribution entitled, "Women studies in Malaysia - a bibliography covering the period 1980 - 1989”. Zainab’s bibliography was compiled as a sequel to Jamilah's work. The resources listed in both bibliographies will be used to ascertain the trends and growth of the body of literature produced on women in the pre1989 years and up to 2004, as well as to make comparisons between the two broad periods in terms of the total number of publications generated, the active authors, the authorship pattern and subject coverage. This study will use bibliometrical methods to analyse bibliographic data. Bibliometrics is a type of research method used in library and information science, where quantitative analysis is applied to describe patterns of publication within a given field or body of literature and their authors (Debruin, Kint, Luwel \& Moed, 1993; ODLIS, 2005).

Both Jamilah and Zainab have listed resources under fairly similar headings. The resources compiled by Zainab's (2006) bibliography were classified under 13 categories while Jamilah (1991) and Fan (1981) had categorized their listings under 12 broad subject areas. Zainab excluded the category "miscellaneous" as most citations collected could be placed within the 13 categories used and had instead included a new category "Technology and science" as there was a growing number of works produced under this category in the recent years. Due to the similarity in the classification used, it was possible to compare literature produce up to 1989 and those up to 2004. The categories used by thee authors are shown in Table 1. 
Table 1: The Categories Used to List the Bibliographies on Women's Studies in Malaysia

Categories Used by Jamilah (1991), Fan (1981)

Categories Used by Zainab (2006)

1. Crime and delinquency

2. Economic conditions, employment aspects, status, and women's role in development

3. Education

4. Feminism and women's rights

5. General works and history

6. Health and welfare

7. Legal status, women and family law

8. Literary aspects, women in literature

9. Marriage and divorce, fertility and demographic studies

10. Muslim women and Islam

11. Political activities and public life

12. Socio-cultural conditions, status in society, sociological and anthropological studies

1. General Works and History

2. Crime and delinquency

3. Economic conditions, employment aspects, status, and women's role in development

4. Education

5. Feminism and women's rights

6. Health and welfare

7. Legal status, women and family law

8. Literary aspects, women in literature, mass media and the arts

9. Marriage and divorce, fertility and demographic studies

10. Muslim women and Islam

11. Political activities and public life

13. Miscellaneous

12. Socio-cultural conditions, status in society, sociological and anthropological studies

13. Technology and science

The categories framed literatures under a broad spectrum of knowledge, basically following the subject classification used by the Library of Congress Classification Scheme: generalia, economics, education, literature and the mass media, law, medicine and health, politics, religion, sociology and technology. The different time frame covered by these bibliographies, with Fan covering studies for the period up to 1980, Jamilah covering the period 1989 to 1989 and Zainab for the period 1990 to 2004, has made it possible to compare and gauge the growth as well as trends of literature generated under the respective categories. This should also help libraries in collection development.

\section{Publications on Women Studies in Malaysia: Up to 1989 and 1990 - 2004}

There was a substantial increase in the publication output of works on women in Malaysia within the 15-year period between 1990 and 2004 compared to those produced before this year span. The quantity of publication refers to the number of publications produced by a researcher or individual in a given field and is used to assess publication productivity (Braun, Glanzel \& Schubert, 1990, Budd, 1995). There is a definite growth in published literature on women studies in Malaysia from 691 publications in the years up to 1989 to 3346 between 1990 and 2004, with the latter period contributing $80 \%$ of total publications produced (Figure 1). For most years in the active period between 1990 and 2004, the number of literature produced totals over 200, except for the year 1991 and 2004 (Figure 2). 


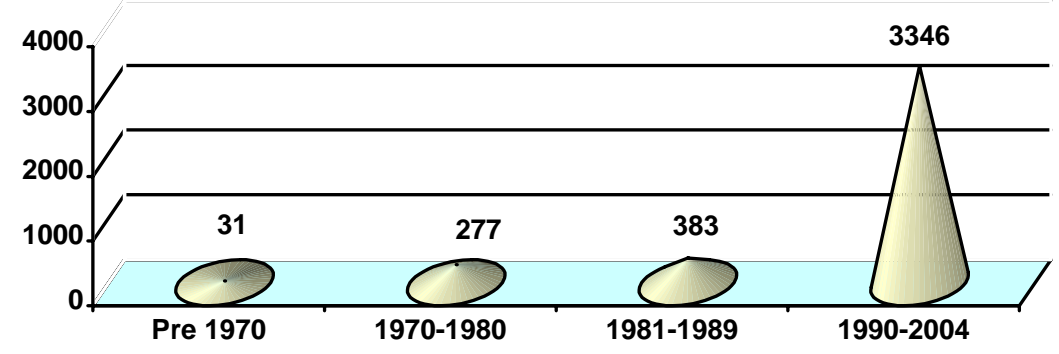

Figure 1: Published Works on Women’s Studies in Malaysia, Pre-1970 - 2004

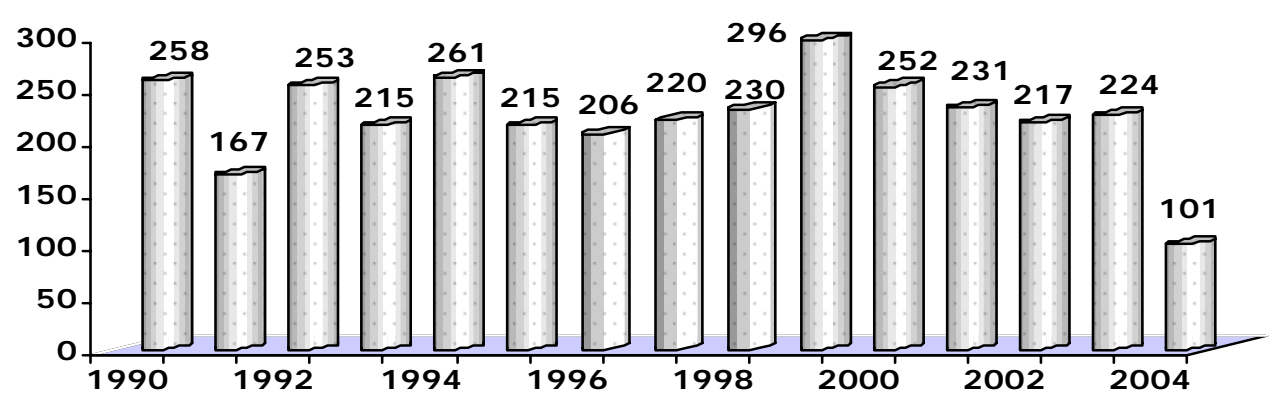

Figure 2: Published Works on Women in Malaysia: 1990 - 2004 (n=3346)

The most productive year was 1999 with 296 publications. The low count for 2004 is expected as Zainab's compilation was completed in 2004 and it would take at least two years before the body of literature produced in a particular year is published and recorded in secondary reference resources such as periodical indexes, databases and online or printed bibliographies. Libraries would also take time to receive and process all research publications deposited by academic staff, undergraduates, postgraduates and those purchased from commercial vendors. The average publication was thus computed to be about 258 per year between 1990 and 2004.

\section{Publications by Broad Subject Categories}

In all broad subject categories the growth of literature published between 1990 and 2004 increased manifolds when compared to the earlier years (Table 2). 
Table 2: Subject Coverage of Works on Women Studies in Malaysia: Pre 1970-2004

\begin{tabular}{|c|c|c|c|}
\hline Broad Subject Categories & Pre 1970 - 1989 & $1990-2004$ & Total \\
\hline 1. General Works \& History - Total & 28 & 226 & 254 \\
\hline General works & 11 & 82 & 254 \\
\hline Bibliographies \& information resources & - & 32 & 32 \\
\hline Biographical works & - & 38 & 38 \\
\hline History & 9 & 48 & 57 \\
\hline Associations, Societies & 4 & 13 & 17 \\
\hline Periodicals & - & 13 & 13 \\
\hline 2. Crimes and Delinquency - Total & 13 & 205 & 218 \\
\hline General works & - & 11 & 11 \\
\hline Correction, Rehabilitation & - & 12 & 12 \\
\hline Sexual harassment & - & 20 & 20 \\
\hline Abuse \& violence against females & - & 89 & 89 \\
\hline Rape victims & - & 18 & 18 \\
\hline Drug abuse & - & 13 & 13 \\
\hline Prostitution & 10 & 8 & 18 \\
\hline Protection & 3 & 7 & 10 \\
\hline Prisoners & - & 15 & 15 \\
\hline Delinquency, deviancy & - & 12 & 12 \\
\hline $\begin{array}{l}\text { 3. Economic Conditions, Employment Aspects, Status and } \\
\text { Women's Role in Development - Total }\end{array}$ & 208 & 667 & 875 \\
\hline General works in development & 39 & 65 & 104 \\
\hline Women in business, retail trade, entrepreneurs & 13 & 136 & 149 \\
\hline Career and employment & 35 & 96 & 131 \\
\hline Coping issues, role conflict & 4 & 35 & 39 \\
\hline Executives, professionals, managers & 6 & 46 & 52 \\
\hline In factories and industries & 36 & 87 & 123 \\
\hline In Agriculture, rural economy & 34 & 75 & 109 \\
\hline Wages, income, salaries & 3 & 18 & 21 \\
\hline As consumers & 5 & 23 & 28 \\
\hline Working mothers, wives & 2 & 11 & 13 \\
\hline Rural -urban migration & 16 & 10 & 26 \\
\hline In trade Unions and societies & 15 & 18 & 33 \\
\hline Migrant, foreign labour & - & 20 & 20 \\
\hline Poverty & - & 27 & 27 \\
\hline 4. Education - Total & 27 & 226 & 253 \\
\hline General works & 14 & 33 & 47 \\
\hline Females in higher education & 4 & 73 & 77 \\
\hline Women teachers & 1 & 28 & 29 \\
\hline School enrolments, performance & - & 25 & 25 \\
\hline Vocational interests, preferences & 1 & 12 & 13 \\
\hline Attitudes, behaviour & - & 13 & 13 \\
\hline Problems, burnout, stress etc & - & 13 & 13 \\
\hline Language in textbooks & 2 & 5 & 7 \\
\hline Extension programme & 5 & 24 & 29 \\
\hline
\end{tabular}




\begin{tabular}{|c|c|c|c|}
\hline 5. Feminism and Women's Rights - Total & 11 & 81 & 92 \\
\hline feminism & 2 & 32 & 34 \\
\hline Women’s rights & 6 & 34 & 40 \\
\hline Freedom, Emancipation & 3 & 8 & 11 \\
\hline Equality, Discrimination & - & 7 & 7 \\
\hline 6. Health and Welfare & 57 & 396 & 453 \\
\hline General health issues & 6 & 15 & 21 \\
\hline Cancer & - & 50 & 50 \\
\hline Other diseases & 5 & 49 & 54 \\
\hline Dietary habit & 1 & 24 & 25 \\
\hline Tobacco habit & - & 5 & 5 \\
\hline Menopause, old age & - & 25 & 25 \\
\hline Maternal health care, welfare, mortality, midwifery & 26 & 52 & 78 \\
\hline Occupational health & 4 & 9 & 13 \\
\hline Family planning, birth control & - & 93 & 93 \\
\hline Breastfeeding, child care & 12 & 40 & 52 \\
\hline Metal and family health & 3 & 22 & 25 \\
\hline Training, profession & - & 12 & 12 \\
\hline 7. Legal status. Women and family law & 79 & 132 & 211 \\
\hline General & 12 & 22 & 34 \\
\hline Legal rights, legal protection & 21 & 14 & 35 \\
\hline Family law & 7 & 33 & 40 \\
\hline Marriage laws, polygamy & 14 & 22 & 36 \\
\hline Islamic law & 8 & 29 & 37 \\
\hline Criminal law & 3 & 1 & 4 \\
\hline Employment, labour law & 3 & 7 & 10 \\
\hline Customary laws & 11 & 4 & 15 \\
\hline 8. Literary aspects, Women in literature - Total & 13 & 319 & 332 \\
\hline Women in literature & 4 & 42 & 46 \\
\hline In mass media & 1 & 56 & 57 \\
\hline Advertisments & - & 18 & 18 \\
\hline In novels, short stories & 6 & 95 & 101 \\
\hline In magazines, newspapers & - & 30 & 30 \\
\hline Broad Subject Categories & $\begin{array}{r}\text { Pre } 1970 \text { - } 1989\end{array}$ & $1990-2004$ & Total \\
\hline Women authors & 2 & 52 & 54 \\
\hline In art, theatre, movies & - & 26 & 26 \\
\hline 9. Marriage, Divorce, Fertility and Demography - Total & 57 & 217 & 274 \\
\hline Marriages & 35 & 91 & 126 \\
\hline Divorces & 6 & 70 & 76 \\
\hline Fertility, reproduction & 12 & 35 & 47 \\
\hline Demography & 4 & 21 & 25 \\
\hline 10. Muslim Women and Islam & 38 & 202 & 240 \\
\hline 11. Political activities and public life & 40 & 102 & 142 \\
\hline $\begin{array}{l}\text { 12. Socio-cultural conditions, status in society, sociological } \\
\text { and anthropological studies - Total }\end{array}$ & 113 & 474 & 587 \\
\hline General & 20 & 52 & 72 \\
\hline Social problems, roles and role conflicts & 10 & 77 & 87 \\
\hline Unmarried women, single mothers & 1 & 31 & 32 \\
\hline Urban, rural women & 50 & 37 & 87 \\
\hline Social life, customs, sexual behavior, kinship & 25 & 111 & 136 \\
\hline Attitudes, opinions, psychology & - & 23 & 23 \\
\hline Associations, societies & - & 23 & 23 \\
\hline Family relations, social class & 3 & 86 & 89 \\
\hline Specific community & 4 & 34 & 38 \\
\hline 13. Technology and science - Total & - & 99 & 99 \\
\hline 14. Miscellaneous - Total & 7 & - & 7 \\
\hline Total for all categories & $\begin{array}{r}691 \\
17.0 \%\end{array}$ & $\begin{array}{r}3346 \\
83.0 \%\end{array}$ & $\begin{array}{r}4037 \\
100 \%\end{array}$ \\
\hline
\end{tabular}


Under Category 1 "General works and history", a substantial number of biographical works on women were written (38 titles). Bibliographical listings began to be compiled between the 1990 and 2004 years (32 titles) as well as writings on the historical aspect of women's social, economics, health and welfare during the British colonial period and Second World War. The subject concerning women in relation to Category 2: "Crimes and delinquency" was hardly reported before 1989 but this changed between 1990 and 2004 when investigations reported issues such as sexual harassment, domestic violence, abusive and violence acts upon women, wives and girls, rape victims and drug abuse among women.

There was a larger body of literature generated under Category 3: "Economic conditions" between the years 1990 and 2004 (667 titles) especially on women in business (136 titles). This was followed by studies about women and careers and employment (96 titles) and the economic contribution of the working women to the industrial and manufacturing sectors (especially the factory workers - 87 titles). There were also new areas not researched before 1989 such as: women and trade unions and worker's associations, and migrant female labour the latter of which mainly came from Indonesia, the Philippines, Cambodia and Burma.

In the education category (Category 4) prior to 1990, research activities covered the general area of women's involvement in education. This which became more focused between 1990 and 2004 to issues concerning female students in higher education (73 titles), women teacher's attitudes, burnout and stress issues among women teachers and the academic performance among female students in schools as well as in higher educational institutions. The category "Feminism and women's rights" for both the pre and post 1990 years covered issues such as women's emancipation, feminism and rights of women in general and in particular the rights of divorcees and wives.

In Category 6: Health and welfare, more literature appeared on family planning, birth control, maternal health care, breastfeeding, child care, women's diseases, especially breast and cervical cancer among Malaysian women. A large body of literature in this category was published in journals.

The next category, Category 7: "Legal status, women and family law" for the years 1990 to 2004 continued to cover issues on women's legal protection or lack of, family laws and legal rights. In Category 8: "Literary aspects, women in literature” in the post 1990s years indicated greater interest on analyzing women's portrayal in novels and short stories, women in the mass media and about women authors. In Category 9: "Marriage and divorce, fertility and demography" there were over 200 titles covering marriage and divorce issues, reproductive rights, child birth, birth control and family planning rights and attitudes. Over 400 titles were concerned with socio-cultural issues such as traditional practices during child birth and pregnancies, the issues on late marriages and unmarried women, the obstacles faced by single mothers and the support systems available for them. Psychological aspects of the urban women were also the focus of studies, such as stress and women's ability to cope with their work and their home responsibilities. A section for the 1990 to 2004 period warranted the addition of a new category - 13: Technology and 
Science, to cover studies on women's role in the science and technological world especially in academia and the school system.

In general, the total count of publications between the pre 1989 years and post 1989 years according to the broad subject categories, totaled to about 4037 publications. Economic and socially-related issues were the most actively researched areas, making up to approximately $35 \%$ of total titles generated. Health and welfare issues literary aspects were equally popular.

\section{Types of Publications Generated}

It is important for libraries to identify what are collectable items and which items could be solicited on exchange basis. The resources listed revealed the type of publications produced by authors on women studies in Malaysia as shown in Figure 3.

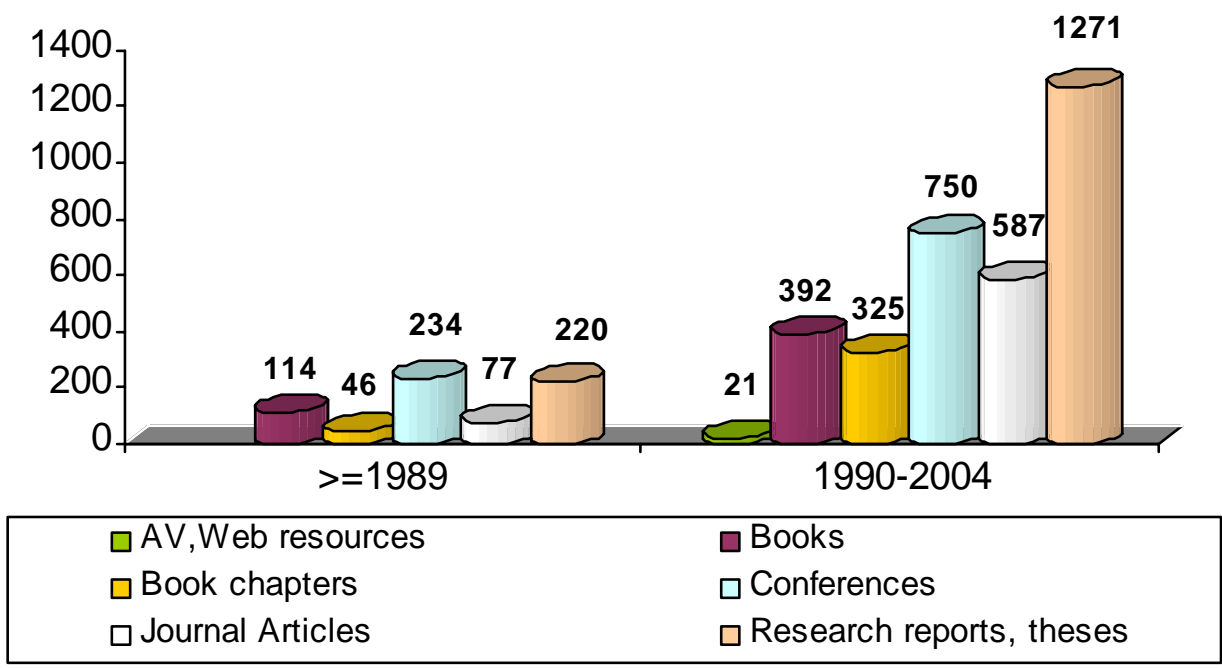

Figure 3: Types of Publications Generated in the Field of Women Studies

The highest type of publications produced were academic research reports generated by staff and students of universities, especially in the form of final year research project reports mainly produced by the Arts and Social Sciences faculties of Malaysian public universities, Masters' dissertations and Doctoral theses. This pattern is similar for both years before and after 1989. Academic research reports amount to about $30 \%$ of total types of materials produced.

The data in Table 3 indicate the distribution of academic research reports produced by selected public universities in Malaysia. 
Table 3: Academic Report, Dissertations and Theses by Institutions: Pre 1989 - 2004

\begin{tabular}{lcll}
\hline Universities & Total & Universities & Total \\
\hline University of Malaya (UM) & 714 & Universiti Malaysia Sarawak (UNIMAS) & 23 \\
Universiti Kebangsaan Malaysia (UKM) & 276 & Universiti Malaysia Sabah (UMS) & 6 \\
Universiti Utara Malaysia (UUM) & 83 & International Islamic University (IIU) & 15 \\
Universiti Teknologi Malaysia (UTM) & 43 & Multimedia University (MMU) & 6 \\
Universitu Sains Malaysia (USM) & 29 & Foreign Universities & 51 \\
Universiti Pertanian Malaysia (UPM) & 25 & Total 1990-2004 & 1271 \\
& & Total >=1989 & 220 \\
\hline
\end{tabular}

In all instances, Universiti Malaya and Universiti Kebangsaan Malaysia were the main contributors, indicating active research on women's studies in these universities. The number of academic reports, dissertations and theses from Universiti Malaya, Universiti Kebangsaan Malaysia and Universiti Utara Malaysia was high because these items were catalogued and access was available from the respective online library catalogue. The other types of publications produced by rank order were conference proceedings, journal articles, books and book chapters.

\section{The Active Authors: Pre 1970 - 2004}

Knowing the active authors in any field of study helps the acquisitions librarian to acquire the core literature in a discipline. The resources listed in the two bibliographies provided the necessary data to identify the authors who have actively contributed to women's studies in Malaysia.

Between 1990 and 2004 a total of 2797 authors contributed works on women in Malaysia, either as single authors, joint authors, editors or compilers (Table 4). Multiple counting of publications was unavoidable as a large number of the single author also authored joint works.

Table 4: The Active Authors on Women Studies in Malaysia, 1990-2004

\begin{tabular}{llrr}
\hline Cohort & Name of Authors & Count & $\begin{array}{r}\text { Cumulative } \\
\text { Count }\end{array}$ \\
\hline 1 & Wazir Jahan Karim & 54 & 54 \\
1 & Jamilah Ariffin & 34 & 88 \\
1 & Ng Cecilia & 32 & 120 \\
1 & Aminah Ahmad & 25 & 145 \\
1 & Maznah Mohamad & 22 & 167 \\
1 & Maimunah Ismail & 20 & 187 \\
2 & Rashidah Shuib & 19 & 225 \\
1 & Rohana Ariffin & 15 & 240 \\
2 & Tey Nai Peng & 14 & 268 \\
& Jariah Masud & & 304 \\
3 & Tan Poo Chang & 12 & \\
\hline
\end{tabular}




\begin{tabular}{|c|c|c|c|}
\hline 2 & $\begin{array}{l}\text { Nik Safiah Karim } \\
\text { Roziah Omar }\end{array}$ & 11 & 326 \\
\hline 3 & $\begin{array}{l}\text { Raihanah Abdullah } \\
\text { Sabitha Marican } \\
\text { Siti Rohani Yahaya }\end{array}$ & 10 & 356 \\
\hline 7 & $\begin{array}{l}\text { Azzan Baharuddin } \\
\text { Chee Heng Leng } \\
\text { Norma Mansor } \\
\text { Rashidah Abdullah } \\
\text { Ravindran, J } \\
\text { Rosnah Baharuddin } \\
\text { Sharifah Zaleha Syed } \\
\text { Hassan }\end{array}$ & 9 & 419 \\
\hline 6 & $\begin{array}{l}\text { Fatimah Hamid Don } \\
\text { Nagaraj, Symala } \\
\text { Nor Aini Abdullah } \\
\text { Nor Aini Haji Idris } \\
\text { Stivens, Maila } \\
\text { Zaleha Kamarudin }\end{array}$ & 8 & 467 \\
\hline 7 & $\begin{array}{l}\text { Chan Lean Heng } \\
\text { Faridah Shahadan } \\
\text { Intan Osman } \\
\text { Rahmah Hashim } \\
\text { Rokiah Talib } \\
\text { Sieh Lee Mei Ling } \\
\text { Siti Aishah Murad }\end{array}$ & 7 & 519 \\
\hline 15 & $\begin{array}{l}\text { Ackerman, Susan } \\
\text { Amarjit Kaur } \\
\text { Chee H L } \\
\text { Da Vanzo, Julie } \\
\text { Fatimah Ali } \\
\text { HanafiahMohd Salleh } \\
\text { Hew Cheng Sim } \\
\text { Khoo Siew Mun } \\
\text { Loh Lee Lee } \\
\text { Noor Rahamah Hj Abu } \\
\text { Bakar } \\
\text { Norani Othman } \\
\text { Shamsuddin K } \\
\text { Siti Fathilah Kamaluddin } \\
\text { Yip C H } \\
\text { Zulkifli Ahmad }\end{array}$ & 6 & 606 \\
\hline 24 & 25 Authors & 5 & 726 \\
\hline 25 & 25 Authors & 4 & 826 \\
\hline 85 & 85 Authors & 3 & 1081 \\
\hline 192 & 192 Authors & 2 & 1465 \\
\hline 2417 & 2417 Authors & 1 & 3882 \\
\hline
\end{tabular}

An overwhelming majority of authors were one time contributors (2417 or $86 \%$ ). This is a common trend among researchers in the social sciences and humanities (Tiew, 1998). Those producing 4 or more articles constituted merely $4 \%$ (108) of total authors involved. A total of 18 authors contributed between 10 to as high as 54 publications. Wazir Jahan Karim who was with the Universiti Sains Malaysia contributed the highest number with 54 publications, followed by Jamilah Arifin and Cecilia Ng from Universiti Malaya with 34 and 32 publications respectively. 
In Universiti Sains Malaysia, the Kanita Project (Projek Kanak-Kanak dan Wanita or Children and Women Project) was started in 1978 and had successfully spearheaded research activities, seminars and workshops, which subsequently resulted in a number of journal articles as well as conference presentations on matters concerning women issues in Malaysia (Wazir-Jahan, 1981; 1990-1991). At the University of Malaya, the Population Studies Unit, at the Faculty of Economics had initiated research activities and generated a substantial body of literature in the form of conference papers, books and journal articles. The strength of research on women studies at the University of Malaya have further progressed with the establishment of the Gender Studies Programme at the Faculty of Arts and Social Science. This indicates that the existence of research centres did help to promote and trigger women studies.

In comparison, the titles listed in Jamilah's bibliography (1991) for the period pre 1970s to 1989 revealed that a total of 449 authors contributed to published works (Table 5).

Table 5: The Active Authors on Women Studies in Malaysia, Pre 1970s - 1989

\begin{tabular}{|c|c|c|c|}
\hline Cohort & Namre of Authors & Count & Cummiative Coum \\
\hline 1 & Jamilah Ariffin & 10 & 18 \\
\hline 1 & Nik Safiah Karim & 17 & 35 \\
\hline 1 & Ahmad Ibrahim & 9 & 44 \\
\hline 2 & $\begin{array}{l}\text { Hirschman, Charles } \\
\text { Tan Poo Chang }\end{array}$ & 6 & 63 \\
\hline 4 & $\begin{array}{l}\text { Azizah Kassim } \\
\text { Fatimah Daud } \\
\text { Ng Cecilia } \\
\text { O'Brien, Leslie }\end{array}$ & 5 & 83 \\
\hline 9 & $\begin{array}{l}\text { Abdul Hadi Zakaria } \\
\text { Nik Zainab Abdul Karim } \\
\text { Noor Farida Ariffin } \\
\text { Nor Laily Azi } \\
\text { Rohana Ariffin } \\
\text { Rokiah Talib } \\
\text { Stivens, Maila } \\
\text { Strange, Heather } \\
\text { Wazir Jahan Karim }\end{array}$ & 4 & 119 \\
\hline 13 & 13 Authors & 3 & 58 \\
\hline 48 & 48 Authors & 2 & 254 \\
\hline 370 & 370 Authors & 1 & 624 \\
\hline
\end{tabular}

Authors who were productive during the early years remained productive after 1990s. This is exemplified by authors such as Jamilah Ariffin who contributed the highest number of publications (18), followed by Nik Safiah Karim (17), and Ahmad Ibrahim (9). In the period 1990-2004, most authors (370 out of 449, 82\%) were published once. Only 9 authors published 5 times or more. This comprises $2 \%$ of total authors. More foreign researchers were involved in women's research in the pre 1989 years than in the later years.

\section{Collaboration Patterns}

Collaboration is an important factor in research especially if the domain is multidisciplinary in nature (Macrina, 2000) and the trend of collaborative research is 
increasing (Price, 1965; Gupta and Karisiddappa, 2000). Often multi-authorship is taken as an indicator of collaboration. The data in Figure 4 reveal that about $87 \%$ of total publications produced were singly authored.

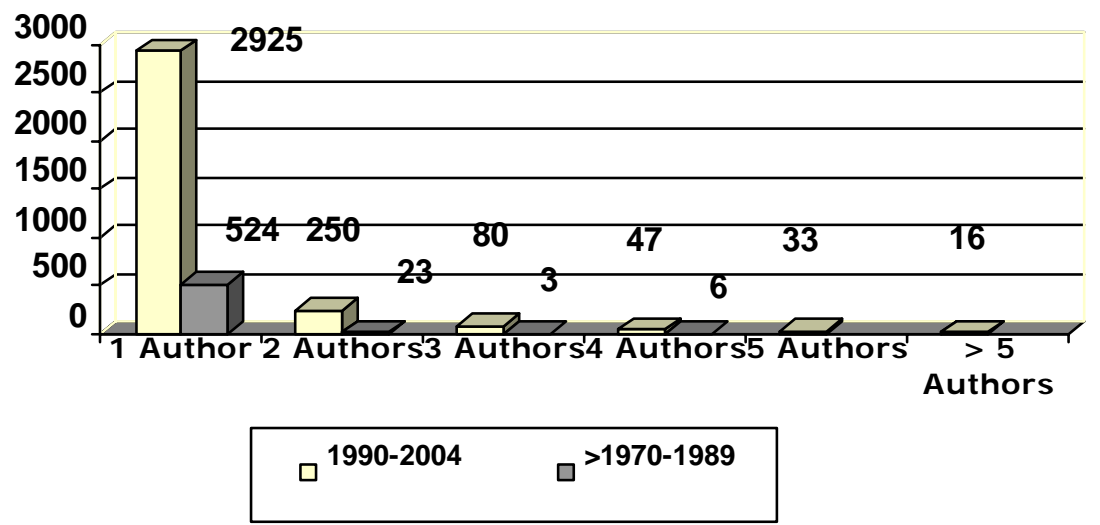

Figure 4: Authorship Pattern of Publications Pre 1970-1989 and 1990-2004

As most of these studies encompassed the fields of Humanities and Social Sciences, this authorship pattern is not surprising, as researchers in these disciplines often prefer to work alone (Stevens, 1956; Stone, 1982, Zainab and Goi, 1997). Most of the publications that were authored by 5 or more authors were in the field of "health and welfare of women in Malaysia”. This predominance of single authored works also the case for works listed in Jamilah's bibliography (1991), where only 32 (4\%) titles were jointly authored by 2 or more authors. The majority of works were singly authored, indicating that researchers on women studies mainly work alone and collaboration is not the norm.

\section{Conclusion}

The data provided by the bibliographical works (Jamilah, 1991; Zainab, 2006) indicate the following:

- There was a substantial increase in the number of literature produced on women in Malaysia between the 1990s and early 2000s. From totals of over 300 publications every 10 years in the pre 1989 years, the amount of publications generated has increased about 8 times to 3346. This indicates a healthy and active research environment.

- There continued to be high interest in studying women in the work place and the focus was on the economic status of those working in factories on the assembly lines, the entrepreneurial ventures and the available support systems for working women. Two other areas that continued to be of high interests were the social-cultural aspects in terms of rites and ceremonies where women were the key players especially in marriage ceremonies amongst the diverse ethnic groups in Malaysia. The problems faced by single mothers and the community support systems available were also highlighted in graduate research studies. Women in the mass media were actively addressed by researchers in Universiti Kebangsaan Malaysia and Universiti Malaya. One area highly studied was the problems faced by women who were subjected to abuse and harassment in the home and the work place. This indicates area that warrants further study to ascertain why this is happening and how women's organisations and governance can provide adequate support to address these issues. 
- Collaborative works are uncommon in the field of women studies in Malaysia. This may be because a large number of women studies are socio-economic based and studies in this field have indicated that researchers often worked alone or in very small groups (Garfield, 1979; Kabir, 1994). The authorship characteristics differ in the Science and technological fields where single authored works are on the decline (Price, 1965; Gupta \& Karisiddappa, 2000).

- Those who were active in the years before 1970 to 1989 continue to be active between 1990 and 2004. The latter years saw an increase in Malaysian researchers and less contributions from foreign researchers.

- One contributing factor to the growth of studies on women is the setting up of centres for research and learning on women studies such as the KANITA project centre in Universiti Sains Malaysia (Wazir-Jahan, 1981) and the Gender Studies Programme at the Universiti Malaya. These two moves have made it possible for women's studies to be managed and promoted to initiate greater research activities in order to sustain the current and future needs and interests. The Kanita Centre for example are offering Masters and doctoral degree programmes.

- Although there have been various bibliographies compiled by individuals especially between the years 1999 and 2004, there is no cohesive collaborative institutional effort. This has resulted in bibliographies which are static and not dynamic. To support research, a dynamic listing would be most helpful. This is feasible and viable in the Internet environment and extremely important in sustaining research activities in any of the subject fields. The Internet can provide a complimentary avenue in the purposeful effort of collating, building and linking "like" and "related" resources both old and new. In reality collaborative bibliographical initiative could be initiated and maintained by a single compiler or a group who would rigorously select items bound by a topic. The framework for such a collaborative bibliographic system was proposed by Hendry and Carlyle (2006) who highlighted the main characteristics of such a system. Firstly, the system would (a) allow for groups of people to participate in the selection decisions, to decide what to include or exclude; (b) enable incremental contributions and growth; (c) support a structured collections of impressive overall size; (d) organize contributors into a structured division of labour; (e) select items based on clear selection policy; and (f) design the system to support an "open bibliography" (allowing anyone to submit and rate items) or a "moderated bibliography" where a single reviewer or a group of reviewers blind-review submissions. Bibliographies are usually compiled by professional librarians or scholars and therefore could be easily differentiated from the listings compiled by amateurs or lone enthusiasts. Kerriemuir (1999) and Bawden and Robinson (2002) evaluated subject gateways and lamented on the large number of people and organizations creating lists or links to resources without any quality control criteria, standard of descriptions and often do not meet the normal standard of bibliographic creations.

- Academic public institutional collaboration is becoming feasible in the case of women' studies in Malaysia, since for the period 1990 to 2004, 38\% (1271) of the 3346 titles come from research activities at the universities in the form of Ph.D. theses, Masters dissertations and final year academic reports. The remainder were literature generated from academic research activities in the form of journal articles and conference papers (40\%) and books and book chapters (20\%). Mutual exchange programmes on a title 
per title basis or non-restrictive inter-library loans could be advantages to institutions serving active researchers in this field. Collaboration and professional intermediation also becomes necessary to support purposeful bibliographic compilations to provide effectively for those seeking information, help sustain researchers' needs and promote possible networking.

\section{References}

Bates, M.J. (1976). Rigorous systematic bibliography. RQ, 16(1), 7-26.

Bawden, D \& Robinson, L. (2002). Internet subject gateways revisited, International Journal Information Management, 22, 157-162.

Bibliografi wanita = Bibliography on women. (1981). Kuala Lumpur: Perpustakaan Negara Malaysia [National Library Malaysia], 31p.

Bibliografi wanita dan media (1991). Edited by Norasiah Haji Harun. Kuala Lumpur: Perpustakaan Penyelidikan, Kementerian Penerangan Malaysia..

Bibliografi wanita Malaysia. (2002). Kuala Lumpur: Perpustakaan Negara Malaysia, 129p.

Braun, T., Glanzel, W. \& Schubert, A. (1990). Publication productivity: from frequency distribution to scientometric indicators. Journal of Information Science, 16, 37-44.

Budd, H.M. (1995). Faculty publishing productivity: an institutional analysiss and comparison with library and other measures. College and Research Libraries, 56(6), 547554.

Dayang Rukiah A.A. (1995). A list of Ph.D theses on women in Malaysia. Kota Kinabalu, Sabah Malaysia: Branch Library, Universiti Kebangsaan Malaysia, Sabah Campus.

Dayang Salwa PPH.A.R. (1996). Wanita: bibliografi beranotasi = Women : an annotated bibliography. Kota Kinabalu: Sabah State Library.

Department of Statistics: official website of Malaysia statistics agency. (2005). Available at: http://www.statistics.gov.my. Retrieved 14 March 2008.

Darby-Williams, R. (1999-2006). Malaysia: women's studies bibliography. University of California, Berkerley Library. Retrieved 14 March 2008 from: http://www.lib.berkeley.edu/SSEAL/SoutheastAsia/seamalay.html

DeBruin, R.E., Kint, A., Luwel. M. \& Moed, H.F. (1993). A study of research evaluation and planning: the University faculty. Research Evaluation, 3, 1-4. 
Fan, K.S. (1981). Bibliography on Women in Malaysia, In: Women in Malaysia, Edited by Hing, Rokiah and Nik Safiah Karim, Kuala Lumpur: Pelanduk Publications.

Fan, K.S. (1982). Women in Southeast Asia: a bibliography. Boston, Mass.: G.K. Hall.

Garfield, E. (1979). Is citation analysis a legitimate evaluation tool? Scientometrics, 1(4), 359-375.

Gupta, B.M. \& Karisiddappa, C.R. (2000). Application of statistical models to the collaborative publications data in theoretical population genetics. Malaysian Journal of Library \& Information Science, 5(1), 37-51.

Hendry, D.G. \& Carlyle, A. (2006). Hotlist or bibliography? A case of genre on the Web, Proceedings of the $39^{\text {th }}$ Hawaii International Conference on System Sciences, 2006.

Retrieved March 2008 from: http://dri.ieeecomputersocietyorg/10.1109/HICSS.2006 $10 \mathrm{p}$.

Hing, A.Y, Nik, S.K. \& Rokiah, T. (eds.) (1984). Women in Malaysia. Petaling Jaya: Pelanduk Publications.

Irvin, J. \& Martin, B.R. (1985). Basic research in the East and West: a comparison of the scientific performance of high energy physics accelerators. Social Studies of Sciences, 15, 293-341.

Jamilah, A. (1991). Women Studies in Malaysia - an overview and reference bibliography. Kuala Lumpur: National Population and Family Development Board.

Kabir. H.S. (1994). Authorship trend and solo research in bibliometrics: a bibliometric study, Library Science with a Slant to Documentation and Information Studies, 31(2), 8190.

Kerriemuir, J. (1999). A brief survey of the Web. Science, (294), 1849-1850.

Khoo, S.M. (1991a). Status and role of Malaysian women on development: a bibliographical essay, observations and policy recommendations. Presented to the Meeting of Project Group at Genting on 15-17 November 1991, 14p.

Khoo, S.M. (1991b). Bibliographical project on women in the library. University of Malaya. Diskusi Pengkajian mengenai Wanita, ke 3, Malaysia: Kuala Lumpur, 16p

ODLIS: Online dictionary and information science. (2005). Retrieved March 2008 from:: http://vax.wcsu.edu/library/odlis.html.

Macrina, F.L. (2000). Scientific integrity: an introductory text with case studies. Washington, ASM Press. 
Martin, B.R. \& Irvine, J. (1983). Assessing basic research: some partial indicators of scientific progress in radio astronomy. Research Policy, 12, 61-90.

Norasiah H.H. (1991). Bibliografi wanita dan media. Kuala Lumpur: Perpustakaan Penyelidikan, Kementerian Penerangan Malaysia.

Price, D.J. De S. (1965). Little science, big science. Columbia: Columbia University Press: 86-91.

Stevens, R.E. (1956). The study of research use of libraries. Library Quarterly, 26, 41-51.

Stone, S. (1982). Progress in documentation, humanities scholars: information needs and uses. Journal of Documentation, 38, 292-313.

Tiew, W.S. (1998). Journal of Malaysian Branch of the Royal Asiatic Society (JMBRAS) 1987-1996: a ten-year bibliometric analysis. Malaysian Journal of Library \& Information Science, 3(2), 49-66.

Wanita Malaysia: suatu bibliography. (1984). Kuala Lumpur: Lembaga Perancangan Keluarga Negara.

Wazir-Jahan K. (1981). The Kanita Project: past policies and future trends. Pulau Pinang: School of Social Sciences, Universiti Sains Malaysia.

Wazir-Jahan K. (1990-1991). Projek Kanita di Universiti Sains dan perkembangannya kea rah Unit Pengajian Wanita dan Sumber Manusia. [The Kanita Project at Universiti Sains and its development towards [the setting up] of the Unit on Women Studies and Human Resource.]. Majlis Diskusi Pengkajian Wanita, Kuala Lumpur, 1 Dis 1990, 19 Jan 1991, 25 Feb 1991 dan 3 Sep 1991. Anjuran Arkib Negara dan Bahagian Hal Ehwal Wanita.

Women's bibliography Malaysia. 1987. Prepared by the National Clearinghouse on Women in Malaysia. Kuala Lumpur: Lembaga Penduduk dan Pembangunan Keluarga Negara Malaysia.

Zainab, A.N. (2006). Studies on women in Malaysia, 1990-2004: An overview and bibliography. Bangi: Universiti Kebangsaan Press.

Zainab, A.N. \& Goi, S.S. (1997). The characteristics of citations used by humanities researchers. Malaysian Journal of Library \& Information Science, 2(2), 19-36. 